\title{
The Attempt To Privatise Business Ethics: A Critique of the Claims of Contractarianism To Be the Ethical Framework for Global Business
}

\author{
G D Donleavy \\ University of Western Sydney, Australia
}

\begin{abstract}
Many issues in business ethics centre on the meaning and scope of the notion; duty of care. Three major ethical frameworks have different ideas about this which are examined in the paper. In particular, the recent claims of Contractarianism in the Academy of Management Review are critically analysed and found wanting to a serious degree. The extent to which Kohlberg's paradigm shares the shortcomings of Contractarianism is then reviewed. It is argued that while Kohlberg is universalist, therefore a recognizably ethical moral framework, it shares with Contractarianism the disadvantage of a problematic a priori rationality in terms of its specifically ethical judgments. Finally, Care Theory is shown recently to have begun to acquire the universalist credentials it previously lacked and not to be subject to the shortcomings of the other two paradigms in some key aspects; but that it still has conceptual development work to do in order to become a practical framework for global business ethics. Such work was inconceivable when Care Theory was relativistic and particularistic, but it now begins to be conceivable as a practical proposition.
\end{abstract}

\section{Keywords}

Attachment, Care Theory, Corporate Culture, Cross Cultural Studies, Gender Identity, Gilligan, Kohlberg

\section{Introduction}

Weber (1926) argued most people's moral decisions are governed by one of two quite different personal frameworks: namely, the ethics of conviction or ethics of responsibility. Conviction covers what one believes to be right but is usually trumped by responsibility which is what one actually does, on the justification of needing to keep the family fed. Conviction resonates with justice, responsibility resonates with care. This does not mean that ethics of conviction connotes lack of responsibility, or ethics of responsibility a lack of conviction. This dichotomy echoes the divide between public life and private life, between our office face and our family one, that the Care Theorists attack but that Kohlberg's framework resolves in favour of the public and the general over the private and particular. One ethical framework, Contractarianism, claims to occupy the middle ground here. Contractarianism has the conviction ethic that honouring agreements is a general good but also has the responsibility ethic that moral obligations arise only from contractual privity between particular individuals including those signing the marriage contract. Another sense in which contractarianism occupies the middle ground is in the range from religious dogma at one extreme to ultra-liberal ethical relativism at

Copyright (C) 2010 Victoria University. This document has been published as part of the Journal of Business Systems, Governance and Ethics in both online and print formats. Educational and non-profit institutions are granted a nonexclusive licence to utilise this document in whole or in part for personal or classroom use without fee, provided that correct attribution and citation are made and this copyright statement is reproduced. Any other usage is prohibited without the express permission of the publisher. the other (Dunfee and Donaldson 1994).

In their Academy of Management Review article, van Oosterhout et al (2006) attempt to advance their project of making ISCT (Integrative Social Contracts Theory) the primary framework of business ethics. The dominant model in business ethics may well, however, still be the Kohlberg model of ethical self development, since 
contractarian theories are usually placed at only stage 5 of Kohlberg's six stage paradigm. At stage 6 are the deontic ethical frameworks usually illustrated by Kant's categorical imperative. Deontic rules are general and universalisable. Contractarian rules are particular and apply only to people who have agreed to them previously. What both perspectives have in common is that the positions they take are the result of reasoned deliberation, with no necessary sourcing in emotion. Both frameworks are attribute a crucial role to hypothetical states of nature in which people coolly reason among themselves which sets of rules will be minimally necessary for the life or projects on which they are about to embark. In a different voice from these approaches is the school associated with Gilligan's critique of Kohlberg, Care Theory. Care Theory grounds ethics in the expressed emotion of caring, both as an empirical and as a normative precondition of any ethics. Care theoreticians reject any theory which resorts to hypothetical states of nature where adults coolly reason out rules. Care Theory regards such imaginary states as so hopelessly unrealistic and faraway from actual human behaviour that they constitute an unsafe and unreliable source from which to validate any ethics. However, it is too early to say that care theory has transcended its partial and relativistic, Kohlberg stage 3 origins; and it is thus more soberly viewed as a promising rather than an already accomplished dominant ethical paradigm. The claims of contractarianism (and its core of Integrated Social Contracts Theory) to that dominance depends very much too much on the very problematic validity of inner morality of contracts, as is deconstructed in the following section.

\section{Contractarianism aka Contractualism}

Van Oosterhout et al (2006) attempt to advance their ambition of making ISCT (Integrative Social Contracts Theory) the primary framework of business ethics using a rather manipulative discourse, as will now be demonstrated.

The first discourse technique used to further this ambition is to stigmatise other contract theoreticians as suffering from "contractual follies'. The four "contractual follies" all happen to display a mellifluous alliteration and they are desolation, deception, defeasance, and defection (van Oosterhout et al, 20006, 527-9) This is an extraordinarily happy linguistic coincidence. Secondly, the writers slide in the occasional unsupported assertion amongst an otherwise densely argued and citation grounded text. The most egregious example of this is the assertion that contractarianism has "more moral substance' than "critics are willing to admit" (op cit, 534), but quite how much that is, and quite who these critics are, is not illuminated. A third example of discourse manipulation is beyond more verbal cosmetics, and is so critical to the writers' thesis that the rest of this section focuses on deconstructing it. The writers triumphantly expose what they call the "contractualist fallacy." This is said to comprise the assertion that since contractualism will uniquely determine a single set of action guiding substantive norms out of all possible sets that satisfy a basic contractualist justificatory argument (op cit 523). They also indict the importation of moral substance from outside the contractualist framework. "Although these two are "conceptually separate fallacies, they tend to go hand in hand empirically. Henceforth we use the term contractualist fallacy to denote both argumentative errors."(ibid). Instead, they say, contractualism 'justifies those norms that free and autonomous agents could and possibly would agree to if they had the choice."(op cit 523). This framework is worth advancing because of its "superior connection with its field of application." (op cit 524)

Contractualism and its near identical twin, contractarianism, involve prior commitments to individualism, freedom, private property rights and the possibility of free market exchange. The approach also involves (op cit 525) "commitments to reasonableness and basic institutions acknowledging the privileged and foundational role of reasoned and voluntary human commitment." Before van Oosterhout, contractualism was originally explained by Dunfee and Donaldson (1994, 1999, 2002a) as lying midway between ethical relativism and ethical absolutism in a way that combines individual contracts with deeper social contracts. It recognizes the authority of such 'key trans-cultural truths' as the idea that all humans deserve respect. It inhabits a 'moral free space' where economic communities and nations have their own norms unless those norms entail 'flagrant neglect of core human values'. The minimum content of a global social contract is arrived in a state of nature and comprises the rights of individuals to voice within and exit from any group and compatibility with 
globally accepted hyper-norms recognized by religions, philosophies and cultural beliefs around the world., especially for businesses these three:

1. firms should adopt adequate health and safety rules for their workers and give them the right to know the risks of doing any relevant jobs,

2. no lies should be told

3. business obligations should be honoured in a spirit of honesty and fairness.

One early version of contractualism regards bribery as wrong, because religions and laws generally condemn it, and because it violates the hyper-norm of public good taking priority over private gain (Sen, 1997)

The "contractualist fallacy" claim has an earlier appearance in Dunfee and Donaldson (2002b, 43) when they try to put 'is' and 'ought' into 'symbiotic harmony in a way requiring both empirical and normative research in rendering ultimate value judgments'. 'Authentic' norms are those supported both by the attitudes and the behaviour of a substantial majority of a community's members (2002b, 45 ), but they only have moral validity if compatible with hyper-norms applying also outside that community. Van Oosterhout et al's $(2006,524)$ footnote 2 says that Dunfee and Donaldson $(1999,4)$ avoid the fallacy by emphasizing 'that the specification of a definitive listing of hyper-norms is not necessary to the understanding and application of ISCT". They believe ISCT is worth advancing despite its compatibility with many contradictory substantive norms "because of its superior connection with its field of application."

Van Oosterhout et al (2006) believe they evade contract fallacies and contractual follies alike by drawing on a major but controversial writer within legal jurisprudence, Lon Fuller. Fuller (1964) famously coined the phrase, the "inner morality" of law, to provide a way of divorcing law from general morality as far as possible but stopping short of a total divorce. Still left inside is the idea that contracts have to rest on trust that the contracts will be honoured, an idea van Oosterhout et al (2006) take up with relish. They make no reference to the wider context within which Fuller wrote, and especially they ignore the Hart-Devlin debate about the necessary or desirable connection of valid law to generally accepted morality. The whole discussion of hypernorms by contractarian advocates from Scanlon to van Oosterhout would be richer, more plausible and less tendentiously presented, had attention been given to the issues and argument in that debate. Van Oosterhout et al (2006) write as if the entire debate had been decisively concluded in favour of the Hart position of no necessary connection between valid law and any framework of morality. The present article takes this no further, however, because the vexed issue of contractualism's need for hypernorms exhumes the most relevant parts of that particular jurisprudential corpse.

The internal morality of law, per Fuller, (1964), was held incompatible with retrospective legislation and with racial discrimination; i.e. those misdeeds are inconsistent with the very idea of law of law and lawfulness., but even the van Oosterhout group have noticed Fuller's inner morality of law was "a morality of aspiration" $(1964,5)$. Now that admission means we are in the realm of imports from other ethical field after all, because the reason why the items constituting the so called inner morality are items worth aspiring to cannot lie within the positive or normative reach of the morality itself - one aspires to what one does not have, not to what one already has. Hereafter we can take it that the moral authority of all sub-species of contractualism, including ISCT, is sourced outside of their own paradigm in the realm of hypernorms and not inside it. That implies it is too far for contractualists to reach to claim their paradigm is, or should be, a dominant paradigm in any field of ethics, including business ethics.

Let us return to van Oosterhout's listing of contractual 'problems' to see what role extra contract hypernorms play in their ISCT's claim to morality.

'Desolation' (van Oosterhout et al, 2006, 527) is the state of solitude said to be experienced by businesses unable to find contracting partners on account of their bounded rationality. It is one of the 4 contracting problems, the problem being apparently that there is no contract at all when perhaps there could reasonably have been one. 
'Deception' is the exploitation of information symmetry by deliberate efforts to mislead - no objection to that, as it is already established in contract law.

'Defeasance' is the problem of the context of the contract unforeseeably changing so significantly that the original consent may not fairly be taken to apply in the new circumstances. This will usually happen by acts of god, but the word defeasance strongly implies fault, except perhaps to an elite band of experienced law teachers, just as the words misfeasance and malfeasance do. It may be wondered whether the alliterative gain worth the substantive loss of meaning.

'Defection' covers all exploitation of post contract information asymmetries, such as free riders, managerial agency cost inducing conduct and subcontracting underperformance. Such behavior falls short of the aspirations for human nature at the heart of the inner morality of contracting, but it is hard how subcontractors and managerial agents can be guilty of defection when they never swore loyalty to the primary contract in the first place Alternatively put, there has first to be a fiduciary duty in order for there to be defection. Van Oosterhout's group says no idea of contract (op cit 528) 'could carry normative force under conditions of slavery or dictatorship, or when processes of exchange and social coordination are predominantly organized in a hierarchical and unilateral fashion' (ibid), but big business is organized in just such a fashion in most industries in most jurisdictions. Van Oosterhout et al (2006) want to 'tame the agent' to cope with defection risks. They recognize the problem of managerial fiduciary duties being unilaterally imposed, mandatory and couched in deontic language for ISCT (op cit 531). Fiduciary duties exist to alleviate problems hampering first order contracting practices but even if they are not, 'there is no reason for contractualists to renounce such moralizing now that contractualism has developed unabashedly moral theories' (ibid). Fiduciarity is thus seen to be supportive of but subservient to contractual integrity. Governments are denied stakeholder status within ISCT however because they 'are involved with authoritatively imposing practical determinations on forms' (op cit 532) Environmental NGOs however are not stakeholders either because either it has contrary interests to those of the form or because it lacks the autonomy or ability necessary to deliver on commitments. However the fiduciary protection afforded to creditors can easily be extended to anyone with a claim against the firm whether for payment or performance (op cit 533) but that includes NGOs and governments, one would have supposed. But they get round that point by deciding that the consideration of who should benefit from managerial fiduciary obligations 'should not be grounded in moral principle' but rather 'result from an empirical analysis of the relative threat of managerial defection each corporate constituency faces in the nexus of contracts that constitute the firm" (op cit 533) This would always put employees top of such list but van Oosterhout et al (2006) do not face that implication.

Buss (2005) closely argues that deceit and manipulation can coexist with autonomy, but it is incompatible with the inner morality of ISCT. Brand-Ballard (2004) argues equally closely that contractualism can only support restrictions on behaviour outside the content of the contract or agreement by importing deontic positions from outside its own framework, a shortcoming even Scanlon concedes. Brand-Ballard (2004) shows how the framework itself could allow cannibalism, consent to being harmed and how it can exclude large blocks of people from its reach, just as the Erasmus article argues governments cannot be stakeholders.

The Erasmus School writers say (van Oosterhout et al, 2006, 522) 'Fuller (1964) saved the moral qualities of law from the amoral claws of legal positivism by focusing on the normative principles immanent in the concept of law itself' and they similarly identify an inner morality of contracting. They aspire to derive norms from within the contract model itself rather than from nature or reason, so they can avoid the contractualist fallacy. They thus deprive themselves both of Scanlon's explicit importation of deontic principles into contractualism and of Dunfee and Donaldson's reliance on global hyper-norms. They praise contractualism's 'content independent normative commitment, based on whatever norms institutions choose to live by which as a result they say "coheres well with liberal democracy and a system of free market exchange" (van Oosterhout et al 2006, 522).

Darwall $(2006,208)$ says that for contractualism, 'mutual accountability is what morality is fundamentally about'. Mutual accountability can be readily widened into general agreement on contractarian principles, and this fits well with the generally accepted principles notion of validity in 
such business disciplines as accounting. This supports the Erasmus school's view that ISCT's close fit to its field of operations, business, makes it fit for the purpose of being the leading paradigm in business ethics.

Darwall (2006) argues that the grounding of morality in mutual accountability rules out state protection of citizens from the consequences of their own folly and that means negative externalities to a contract are born by everyone within and outside the contract. There is no rule against imposing externalities in ISCT, and Scanlonian hyper-norms that do frown on such conduct are conceded by Scanlon to be deontic imports rather than part of contractualism's own inner morality. Scanlon puts inside the inner morality the notion of representation so that he sees a moral claim by someone who has been led to believe something on the person who made the representation, and such a claim lies inside the inner morality. The nature of this claim lies outside of strict contract privity and begins to bridge the gap between contractualism strictly defined and the fiduciary duty idea which vexes the Erasmus writers.

The English Court of Appeal has recently concluded that not every breach of duty by a professional on a contract for services is a breach of fiduciary duty in Bristol and West Building Society v. Mathew [1996] 4 All E.R. 698 (C.A). In particular, a trustee's duty to exercise reasonable care, although equitable, is not specifically a fiduciary duty. "Breach of fiduciary duty" connotes disloyalty or infidelity. Mere incompetence is not enough. A servant who loyally does his incompetent best for his master is not unfaithful and is not guilty of breach of fiduciary duty.

Even assuming that consent is normatively significant, why should we think that hypothetical consent has any normative force? (Is it morally permissible for you to take my car without asking me, just because I would have consented had you asked?)

Jean Hampton (1998) criticized Hobbes in her book "Hobbes and the Social Contract Tradition", arguing that the characterization of individuals in the state of nature leads to a dilemma. Hobbes' state of nature as a potential war of all against all can be generated either as a result of passions (greed and fear, in particular) or rationality (prisoner's dilemma reasoning, in which the rational players each choose to renege on agreements made with each other). But if the passions account is correct, then Hampton (1998) argues, the contractors will still be motivated by these passions after the social contract is drawn up, and so will fail to comply with it. And if the rationality account is correct, then rational actors will not comply with the social contract any more than they will cooperate with each other before it is made.

In an important article, "On Being the Object of Property," African-American law professor Williams (1988) offers a critique of the contract metaphor because by defining some as contractors and others as incapable of contract, whole classes of people can be excluded from the realm of justice. This point has been taken up by other critics of contractarianism, such as Kittay (1999) who points out that not only are dependents such as children and disabled people left out of consideration by contractarian theories. This objection has been recognized by Scanlon who would appoint trustees able to contract on behalf of the contractually disabled but this simply creates a new field for the problems of fiduciary duty to grow.

A descriptive use to which contractarianism has recently been put is to exploit the in-group/out-group nature of the contractarian project to illuminate the phenomenon of oppression. The moral terms require the dominant group to evaluate the lives of their group more highly than those of the subordinated, the political to deprive the subordinate group of effective political power, and the epistemological terms require the members of the dominant group to see themselves as intellectually superior to the dominated. The social contract then can be seen as a justification by the parties to the contract of their interaction, and of their exploitation of those who are not parties to the contract, but only if the fundamental division of in-group and out-group is accepted. If the racial and sexual contracts were to be shown to be rational, they would constitute prima facie critiques of normative contractarianism, since they would then seem to justify racism and sexism.

Several of the critiques surveyed above, then, centre on the questions: who is allowed to be a party to the contract, and how are those who are excluded from the contract to be treated? On the normative contractarian view, it is only rational to include all of those who can both benefit and reciprocate 
benefits to others. Normative contractarianism, then, on the assumption that non-whites and women can both benefit and reciprocate benefits to others, shows the sexual and racial contracts to be fundamentally irrational. Disability rights activists, however, would still have a serious complaint to lodge against normative contractarianism, since it is surely the case that there are persons who cannot reciprocate benefits to others. Such persons would be, on the normative contractarian view, beyond the scope of the rules of justice.

There are contenders for the title of leading paradigm in business ethics, though none are led so aggressively to stake that claim as the Erasmus School has led ISCT. Rights theorists (such as libertarians) claim that morality is grounded in non-violation of rights (such as respecting actual agreements), utilitarians claim that it is in promotion of welfare, and some care theorists assert that it is concern for others. Parts of these paradigms are compatible with ICST, but parts are not. Is such incompatibility merely exemplifying the so called contractualist fallacy or is the Erasmus School doing the very thing they warn against (van Oosterhout et al, 2006, 523) - having their cake and eating it too? This section has provided grounds for thinking that that is very much the ase.

The Van Oosterhout version of ISCT, with its discomfort about fiduciary duty, its view that anything goes if reasonable people could possibly agree with it, and its ignoring of any possible ethical claims on a business's behaviour by people neither stakeholders nor contractees makes their ISCT barely recognizable as an ethical framework at all. The earlier and significantly different Dunfee and Donaldson version of ISCT, however, ascribes a key role to hypernorms and generally recognized ethical principles, so that freedom to contract and to implement contract terms is for them conditional on compliance with norms imported from outside of the contractualist framework. Since those imports are mostly drawn from the postulates of Care Theory and from Kohlberg's post conventional frameworks, these are discussed next.

\section{Kohlberg's Universal Paradigm of Moral Development}

Kohlberg's paradigm describes six stages in an individual's potential moral evolution. Amoral and immoral individuals are off the scale altogether. At stage 1, an individual behaves ethically only to the extent $\mathrm{s} / \mathrm{he}$ fears punishment for wrong doing. At stage 2, fear is supplemented by pleasure as good behaviour is rewarded, as well as bad behaviour being punished. At stage 3, the 'need to belong' is the drive which ensures good behaviour by compliance with the group's norms. There will be membership of different groups in different strengths, only a few of which will shape the individual's moral identity. At stage 4 the group has extended to become all of society, that is, the country, race, or homeland. At stage 5 the individual has thought out his/her own moral views and come to adopt utilitarianism or social contractarianism as a dominant moral philosophy. At stage 6 the individual arrives at deontological positions guided by an overarching moral principle such as the Golden Mean or the Categorical Imperative. Each stage is meant to be not only a chronological and a developmental evolution from the previous one but also to be morally superior to it. Kohlberg has been criticized for lacking empirical evidence for the existence, let alone the primacy, of his stage six (Meiland, 1980).

The dominance of Kohlberg's paradigm is evidenced by its major role in sourcing such subsequently conceived ethical models as:- Ferrell and Gresham's (1985) "Contingency Framework for Ethical Decision Making in Organizations"; Trevino's (1986) "Person-situation Interactionist Model"; and Hunt and Vitell's (1986) "General Theory of Marketing Ethics." Studies by Derry (1989), Dukerich et al. (1986), Trevino and Youngblood (1990), Weber (1990), Goolsby and Hunt (1992), Ponemon and Gabhart (1993) and Snell (1996) and others, in a wide range of organizational settings, have provided general empirical support for the first four stages of Kohlberg's paradigm.

\section{Gilligan's Critique of the Kohlberg Paradigm}

Gilligan $(1977,1979,1982)$ rejected Kohlberg's taxonomy of stages in ethical development as exclusively male-oriented. Gilligan (1982) illustrates how women emphasize the notion of "caring" in the cognitive handling of ethical dilemmas whereas male values centre on a "justice" concept.

She says $(1982,19)$ 
"This conception of morality as concerned with the activity of care centers moral development around the understanding of responsibility and relationships, just as the conception of morality as fairness ties moral development to the understanding of rights and rules."

Males' moral development is claimed to be based on individuality whereas females' is based on connectedness (Gilligan 1977). She asserts that females are mis-scored on Kohlberg-type scales, thus causing women to manifest lower scores. Gilligan attributed this to the tests' inherent male bias, which regards the care focus of Kohlberg stage 3 as only half way to the alleged moral maturity of Kohlberg stage 6 deontology.

Skoe's (1994) findings indicate that both the care and justice aspects of moral development are related to identity for both men and women students. Women had a stronger relationship between identity and care than that between identity and justice.

\section{Care Theory}

The mainstream tradition in ethical philosophy has been to consider rational thinking about a supposed a priori moral law self-evidently more valid than passionate attachment and engagement, but strong feminist critiques of the sexism inherent in such philosophical privileging of a predominantly male mind set have been published by Baier (1985, 1987), Young (1987), Friedman (1987), Held (1987a and b) and Okin (1989) Seidler (1989), and Ruddick (1994). More recent feminist work (Acker 1991, Court 1994, Davies 1992, Gherardi 1994) has sharply questioned the traditional binary opposition of a rational public masculine world against an affective private feminine one.

Care theory believes people are primarily relational not individual or free. Virginia Held (1993: 195) asks what if the paradigm in western philosophy of economic man were replaced by the mother and child as the primary social relation. Tronto (1993:8) asserts the traditional liberal moral viewpoint requires such disinterest as to be beyond any attachment, engrossment and emotion and such disinterest is well symbolized in the icon of blindfolded justice. Commitment to others, to community, or to locality is seen as compromising rational judgment (Wood 1994:43). An ethic of care, however, makes ignoring others a kind of evil (Tronto 1993:130). It has expanded so far in feminist studies that it has been applied even to agricultural policy (Curry 2002). Care Theory has caring and attachment as foundational in sharp contrast to their quarantined position in the Kohlberg paradigm at stage 3 .

The early descriptions of the ethic of care contrasted care with principled thinking, as 'to care is to act not by fixed rules but affection and regard' (Noddings, 1984, 245). Later, some critics have argued that the ethic of care has to be guided by principles and ideals in order to be extended to strangers (Flanagan, 1991; Hoffman, 2000).

Engster (2005) quotes a strong characterization of care by Tronto $(1993,103)$ as

"..everything we do to maintain continue and repair our world so that we can live in it as well as possible. That would include our bodies, ourselves and our environment, all of which we seek to interweave in a complex, life sustaining web."

This scope of this view of care is expanded by Schwarzenbach $(1996,102)$ thus,

"all those rational activities (thinking about particular others and their needs, caring for them, cooking their meals etc) which go toward reproducing a particular set of relations between people over time - in the best understanding - my thesis runs - relations of philia".

Schwarzenbach (1996) distinguishes caring from productive labour as the latter is done in order to contribute to sustaining life and relationships while caring is about ends not means, about the sustenance of relationships themselves. Caring for self is also legitimate say Gilligan (1982), Tronto (1993) and Slote (2000), though this obviously becomes self indulgence when in excess. Caring is neither a positive nor negative attribute but instead forms part of a subjectively experienced relationship, which may be used both to control and/or to empower others (Chodorow 1978, Court 1994). 
Gilligan (1982) claimed that just as the ethic of justice constitutes a developmental sequence, the ethic of care does so as well. She proposed that care development would entail three main levels of care with two transitional ones from (1) initial self-concern, through (2) exclusive other-oriented concern to (3) the balanced concern for both self and others. Pivotal for the development of care is a growing understanding of responsibilities in the context of more differentiated dynamics between self and other. Gilligan herself withdrew from studying development, but Skoe (1993) continued that work by constructing and validating the developmental measure of care-based moral reasoning, the Ethic of Care Interview (the ECI hereafter). The ECI consists of a self-generated real-life conflict and three standard interpersonal dilemmas surrounding (a) unplanned pregnancy, (b) marital fidelity and (c) care for a parent. These dilemmas were included in the measurement to show usual real-life situations of interpersonal concerns, where helping others could be at the price of hurting oneself (Skoe \& Marcia, 1991). Recent research from the 1990s onwards has established the Gilligan stages but only with cross-sectional data (for a review, see Skoe, 1998). Levels of care reasoning have been found to be positively correlated with such developmental indexes as age and identity development (Skoe \& Marcia, 1991; Skoe \& Diessner, 1994, Skoe \& von der Lippe, 2002), justice development (Skoe \& Diessner, 1994; Juujarvi, 2005), and women's gender roles (Skoe, 1995). Only one longitudinal study to date (Juujarvi, 2006a), however, has lent support to the existence of Gilligan's developmental stages.

Caring involves respect for the recipients of care as equals rather than as pitiable victims or ignorant lesser beings, claims Engster (2005). Examples of the latter problem are especially strong in social work. For example, mothers who resist social work care too strongly run the risk of being positioned as pathological. Deference to care workers ensues from this, and dependence on the care workers is encouraged. Moreover, caring talk foregrounds a particular, needy, often sentimentalized image of the child and discloses how care discourse can be used as a mechanism of control, even oppression, quite as readily as more traditionally masculine discourses. (Marks 1997:96)

However, caring does not mean, or even necessarily include, schmaltzy over-indulgence of spoilt offspring by co-dependent mothers, but it simply requires that one is feeling bonded or attached. Dally (1992:8) importantly distinguishes 'caring for' from 'caring about'. The former has to do with the tasks of attending to another person and is the work of the caring professions. The second is just about feelings. Caring for can involve emotional distancing. For example, Menzies Lyth (1988) shows how nurses uses a range of devices such as reification, thoughtlessness and ward rotation to avoid getting too stressed by proximity to illness, distress and death of their patients. This is the opposite of the attachment that caring about involves and yet is clearly still caring.

Engster (2005) attempts to ground a general paradigm on the basis of care theory by extending the work of such writers as Fineman (2004) and Kittay (1999) who had grounded their own assertion of a general duty of care on the evident fact of our general inter-dependency. They in turn had developed their view from Goodwin (1985)'s and Clement (1996)'s earlier grounding of a general care duty in our not quite so readily evident fact of our condition of general vulnerability to others. Baier (1985) said what makes us human is the care we receive from others and that all unhealthy and sociopathic behavior could be traced back to a deficiency of care. Kittay (1999) asserts that society would cease to exist altogether if nobody cared for anyone else, the implication being that care is a general duty because society must self-evidently be sustained. Fineman $(2004,48)$ agrees and focuses on 'caring for' rather than caring about in her assertion: "It is caretaking labour that produces and reproduces society."

Held (1993, 195) says social contract theories of a Rawlesian or Hobbesian type which begin with independent man in a state of nature are wrong, since such a state of nature is quite impossible and therefore cannot validly serve as a starting point for any theory, positive or normative, of human nature, inasmuch as any so called independent men would have begun life as babies dependent on mothers. Folbre (2001) applies similar criticisms to market and contractualist based morality paradigms, saying that productive labour and entrepreneurs first have to be bred and raised, and someone has to care enough to make that happen. Finally from this perspective, Kittay $(2001,535)$ says the duty to care should be seen as a "categorical imperative...derivable from universalizing our own understanding that were we in such a situation, helpless and unable to fend for ourselves, we 
would need to care to survive and thrive." Engster (2005) wonders if there exists a basic human right to obtain care when it is needed, on the grounds that the such a right is a prerequisite of human survival, survival being taken to be a self evident basic good. From here he ingeniously proceeds to make Care Theory's particularity and relativism into a general theory in the following manner. Because resources of money, time and energy are limited, care effort has to be allocated according to some sort of priority schema, and it is reasonable and efficient for us to care more for those especially dependent on us such as our intimate family. This includes a primary duty to care for ourselves enough to prevent us becoming an unnecessary burden on others. This 'universal principle of partiality' is the core of Engster's general care theory project. It means each person should care primarily for her/his intimates and dependants because generally that will distribute care resources most effectively across society. As for those left out and uncared for by their intimates, they become the responsibility of everyone, though he does not say how resources can consistently, fairly or effectively be allocated to such unfortunates whose numbers may be rather large and increasing over time. This general theory of care is strongly idealistic, but it is certainly logical and internally coherent and does provide a basic toolkit with which to tackle other paradigms from Kohlberg to contractarianism and so to move Care Theory off the back foot where personal and particularized feelings have been defensive against the lofty claims of impartial reason. This is quite a notable step, and we can expect the next few years to see major advances in the attempts to build general theories of morality that attend to the criticisms rival schools have long made of each other. Any such development would resonate across business ethics studies, and could unsettle the view that business acculturates both genders so strongly that gender differences converge. More radically, such a development could provide an interesting alternative perspective to CSR from that provided by stakeholder theory and contractarianism, neither of which have a great role for caring as a driving force.

\section{Corporate Culture's Filtration of Ethical Orientations}

Kelley, Ferrell, and Skinner (1990) suggest that employees after three to five years on a job may experience work frustration, which may cause them to compromise their ethical values to advance their careers. Harris (1990), on the other hand, found that managers employed by an organization for at least ten years, were less tolerant of fraudulent practices than other employees. A study of top managers' perceptions of moral issues in stakeholder relations found that younger respondents, respondents with lower income, and respondents with shorter managerial experience have less positive attitudes toward moral issues in stakeholder relations; whereas older respondents, respondents with the highest income, and respondents with longer managerial experience, have more positive attitudes toward moral issues in stakeholders relations (Kujala, 1995, 70). It seems that attachment (to a firm) does play a role in assessing ethics.

The Social Bonding Model has an explicit place for attachment, as well as for its 3 other elements;commitment, involvement and belief. Attachment and involvement were significant predictors of rule breaking in a Sims' (2002) 200-employee South Florida sample. The Social Bonding Model was developed by Hirschi (1969) who proposed that the greater the social bond, the greater the likelihood of conformity to society's expectations. Attachment determines whose interests will be regarded as mattering and even whose norms will be internalized. (Hirschi 1969:18) 'Commitment', however, means caring about what would be lost if they were to break the rules. 'Involvement' means involvement in activities to an extent that leaves little time to rule break. 'Belief' means belief in society's norms. Hollinger (1986) suggested operationalising such attachment by measures of job satisfaction. No gender differences were found but job dissatisfaction did play a big role in predicting rule breaking intention and tolerance. This result supports both the role of attachment itself and of the other attributes to which it is (perhaps inextricably) linked.

Cohen (1995) plausibly asserts that top management sets the moral tone for the organization and is primarily responsible for establishing and maintaining the moral climate of the organization. This was already believed in Renaissance Europe and is a primary theme of such Elizabethan dramas as the Duchess of Malfi, King Lear and Hamlet. According to D'Aquila (1997), managers, especially top managers, set the tone of the organizational climate to such an extent that senior employees might gravitate to the perceived ethical climate type of their ethical tendency, since members of a 
corporation that do not fit tend to move to a corporate environment within which they feel comfortable. Victor and Cullen $(1987,1988)$ studied the link between corporate ethical standards and organizational behavior. Using their specially designed instrument and factor analysis, they classified organizations into categories of distinct ethical climate types (Caring, Law and Code, Rule, Instrumental, and Independence). They also found that climate types influence managerial behavior and that climate types influence what ethical conflicts are considered and the process by which the conflicts are resolved

\section{Concluding Discussion}

If van Oosterhout et al $(2006,524)$ are right that ISCT should be the dominant framework in business ethics because of its superior fit to its field of operation, then there can be no fiduciary duty, no corporate social responsibility and no constraints on business behavior outside that permitted by agency theory grounded monitoring and bonding mechanisms. To put it more plainly, business should be free to set its own rules on the foundation of private contractual agreement. Ethics should thus be privatized.

For Kohlberg ethics are either universal or they are not ethics at all. He would see privatized ethics as an obvious oxymoron. The ISCT of Dunfee and Donaldson has a strong role for hypernorms, generally agreed ethical principles between all religions and similar established movements. For them the contractarianism of consent operates on a general societal level, not simply on a business to business one. This is stage 5 thinking on the Kohlberg scale. Its claim to dominance ethically depends on

1. the extent to which the claims of non contractors are given moral authority,

2. the sharpening of the boundary between the jurisdiction of contract terms and the jurisdiction of hypernorms

3. the evidence supporting the notion that consent based morality leads to clearer ethical thinking, better ethical conduct and more effective integration of words and deeds, of responsibility and conviction than other moral frameworks.

The Kohlberg paradigm has survived attacks on its gender bias, largely due to the acculturation and homogenization of ethical attitudes within strongly codified business firms with strong corporate cultures. However, the DIT which is its principal mode of gathering empirical support confounds stages 2 and 3 and also stages 5 and 6 . Consequently these stages remain matters only of opinion and empirical support is only for evolution from pre-conventional to conventional to post conventional stages. The strong differences between stages 2 and 3 in theory are not accessible by DIT mediated empirical evidence.

The completely separate identities of stages 5 and 6 in Kohlberg's earlier design was confounded by the man himself in his later work. There is no a priory reason and no empirical evidence published to support the notion that deontological frameworks such as Kant's are superior or come later in ethical development than the contractarianism or utilitarianism of stage 5. It is not even clear that graduation from stage 5 act utilitarianism to rule utilitarianism is also a graduation to stage 6 ; or that it matters to anyone if it is!

It is suggested that the reason for the dominance of the Kohlberg paradigm is its elegance as a framework, its neat pigeonholing of major schools of ethical philosophy and its very crude but very clear empirical support. That is, there is empirical support for the phenomenon of ethical development roughly along Kohlbergian lines - but only very roughly. It could be that it is vulnerable to any new framework equally clear in its sequences, equally comprehensive in its purported scope and equally capable of generating instruments with good construct validity with which to test its empirical support.

Kohlberg et al (1983) and Higgins (1989) claim CMD encompasses care as well as justice. Colby et al (1983) argue care, relation and trust are elements in each of the Moral Judgment Interview (MJI) scoring schemes often used in earlier research. Others argue that since care reasoning can be elicited by the MJI dilemmas, a separate theoretical and psychometric structure is unnecessary (Walker et al 1987, Wark and Krebs 1996). Gilligan's contention that care and justice represent distinct moral 
perspectives is still just a contention, while her attribution of the former to males and latter to females has not yet received any significant empirical support, as shown in previous sections. Reed (1997, 254/5) goes as far as to claim that "Gilligan and Kohlberg and their colleagues now offer conceptions of moral maturity that are for all practical purposes indistinguishable" because he claims to see in Kohlberg's later writing an idea of benevolence at stage six that is akin to balanced care at Gilligan's mature stage. This is not echoed by any other later writers cited in the journals reviewed for this paper except for Jorgensen (2006) who does say the distance is not very great between the final Kohlberg stage and the final Gilligan stage. In the Kohlberg one, "universalizability and reversibility constitute self conscious validity checks on one's reasoning" (Kohlberg 1986, 490). In the Gilligan one, caring "becomes universal in its condemnation of exploitation and hurt" (Gilligan 1982, 74). Jorgensen is still going too far, for all that is similar here is the identification of universality rather than universalisability of both writers' characterization of the perspectives achieved at the final stages of their respective models. To put it more plainly, what is similar in their final stages is only that those stages are both final. It is surely inherent in the final stage of any psychological paradigm of development that the perspective should more general and less particular than the perspective of earlier stages.

Care theory started in the specifically limited area of female issues over abortion, moved to problematise the public private split which kept apart ethics of conviction from ethics of responsibility for so many people over so many generations, and has lately generated its first attempts at universalizability.

Jorgensen (2006) evidences Kohlberg (1978)'s recognition of moral judgment as only one element in moral behaviour, albeit the most influential one. Moral behaviour is situational and Kohlberg (1986, 500) saw Gilligan's care perspective as enlarging the social cognitive domain of morality rather than rejecting the distinctive justice domain within moral judgment. In other words, she focuses on behaviour which Kohlberg admits is generally situational, whereas he focuses on judgment which is said to be cognitive and general, and indeed a priori in that it is brought to behavioural situations as a ready-made tool for use in those situations.

A large body of research on real-life morality has validated that people use both ways of moral reasoning in resolving real-life conflicts. Further, it seems that the most important determinant of moral reasoning is the content of the moral dilemma, rather than the gender of respondents (for a review, see Jaffee \& Hyde, 2000). Johnston (1988) found boys would not use care orientation unless they believed the relationship between the characters could be salvaged. More recent research has shown that pro-social dilemmas that involve concerns about others' welfare tend to invoke care-based arguments, whereas anti-social dilemmas that involve transgressions and temptations tend to invoke justice-based arguments (Wark \& Krebs, 1996, 1997, 2000 Haviv \& Leman, 2002; Juujarvi, 2006b). The Kohlberg level of justice reasoning for real-life moral dilemmas tends to vary according to the type of dilemma (Krebs et al, 1991; Wark \& Krebs, 1996, 1997; Haviv \& Leman, 2002). Antisocial dilemmas especially tend to invoke low-stage moral judgments (Wark \& Krebs, 1996, 1997; Haviv \& Leman, 2002). Some studies (Linn 1995; Juujarvi, 2006a) have further found that complex real-life dilemmas involving conflicting rights or social pressure against one's own moral values - akin to Kohlberg's hypothetical dilemmas - invoke high-level justice reasoning. Very recently, Juujarvi's (2006b) results (using Skoe's ECI) show that antisocial temptation and transgression dilemmas tended to invoke lower levels of care reasoning than conflicting-demands and social-pressure dilemmas. Participants reporting temptation dilemmas had the least developed care reasoning. The results suggest that subjects identified at different care levels perceive different types of real-life moral conflict, and that the function of care reasoning varies according to the type of moral conflict. These studies suggest that the employment of care or justice reasoning is much more to do with the dilemma or situation in which judgment is to be called for than to do with the ex ante mind set of the person approaching the situation. This would perhaps explain why abortion dilemmas invoke care in Gilligan's main work while the DIT invokes justice reasoning and support for Kohlberg's CMD. The gender difference and the ethical framework differences may well be primarily explained by the dilemmas themselves rather than by the conditioning of the subjects interviewed. 
While the Gilligan critique of Kohlberg on gender grounds has not been at all well supported by empirical research, its offspring, Care Theory has been very successful in surfacing and problematising assumptions underpinning the ethical frameworks pegged to Kohlberg stages 5 and 6 .

First, care theory denies the validity of impartiality as the basis of ethical reasoning or of ethics itself.

Second, it disagrees with excluding oneself from the purview of those to whom a duty may be owed.

Third, it strongly attacks the division of life between public and private, with the former dominated by males, by "serious issues" and the ethics of conviction; the latter by females, by domestic issues and the ethic of responsibility.

Fourth, it does not accept the view of Kohlberg (or Kant, inter alia) that ethics are general and universal but believe them to be coterminous with the reach of care, stronger with those in one's inner circle, weaker with strangers. Kohlberg's Universalist view of ethics means his first three stages are in his own set of values, pre ethical since they are from universal - stage 4 too arguably before the United Nations was set up in 1946. Care theory is thus for Kohlberg pre ethical because it is like his stage three in its primacy of personal loyalties over general duties.

The four aspects of Care Theory just listed are not easily reconciled with Kohlberg's framework and are not meant to be. It is possible to explore the middle ground between them, to design possible bridges between them and to suggest when one might be more appropriate or is empirically more apt to be employed in decision making than the other. For example, Strike (2000) says moral capacities such as empathy and sympathy occupy a space between rights and Care Theory because, while they depend more on attachments than principles, they are evoked by characteristics of others that are not rooted in group membership or shared identities. In other words, empathy could be evoked by strangers one has not preciously cared about. For Kohlberg, such triggers of universality were a crucial element of ethics. That is, he followed the western liberal tradition of seeing a principle as needing to be universal in order to have any meaning at all. However, we have already noted recent attempts by Care Theory supporters to ground it too in universal principles. It can therefore be said to have dealt with its earlier (apparent) problem of appearing indifferent to strangers.

For the purposes of this paper however the point is to assess the possible contribution the new care theory can make to business ethics. Can a framework sourced in the ethics of abortion decisions and in radical feminism have anything foreseeable usable for business jurisprudence, especially when the field is already full to overflowing with regulatory paradigms from other sources nearer to everyday business reality? Even if it does, any application of care theory would add to the business's regulatory burden of fiduciary duties and post SOX extended audit burdens so would not easily be internalized by entrepreneurs.

Yet when we consider the revolution in philanthropy that followed band aid in 1984 and the Gates Soros - Branson transformations, it seems possible that care can be ignited by charismatic leadership and example. Such care embeds a sense of duty grounded in compassion or the same desire to make the world a better place that led some to enter business in the first place. Fiduciary duty is more easily discharged if you care about your stakeholders but there are too many of them for it to be particular and individual. Care theory would therefore have to import principle from the more traditional frameworks so as to universalize the duty of care, as care theory has recently begun to realize. This can be joined to the more traditional business value of service. Service to customers and to other stakeholders reaches down the Kohlberg ladder to stage two where the game theory approach to competition dominates, The one shot game allows for betrayal, especially in prisoners dilemmas, but when a game is to be repeated and relationships are to be built, then service and reliability become necessary to maintain the business relationship. This itself requires care. What care theory offers business is an ethic of sincerity rather than instrumentality with which to bond, to relate to and to fully engage with stakeholders - and the other frameworks do not have this in their portfolio. Such an application of care theory would raise the stakes of doing business, since bad service, indifference to stakeholders and negligence would be punished severely by stakeholders betrayed by companies cynically using service and care discourse but not acting on it. Call centres would with luck be the first casualty of such a development. 


\section{References}

Baier, Annette :1985, “What Do Women Want In Moral Theory?”, Nous 19, 53-63.

Baier, Annette:1987, "The Need For More Justice", in Marsha Hanen and Brand- Ballard, Jeffrey, 2004, "Contractualism and Deontic Restrictions", Ethics 114(2), January, 269-300.

Buss, Sarah, 2005, "Valuing Autonomy and Respecting Persons: Manipulation, Seduction, and the Base."Ethics; 115(2); January, 195-235.

Chodorow, N.; 1978, The Reproduction of Mothering: Psychoanalysis and the Sociology of Gender, (University of California Press, Berkeley).

Clement, G: 1996, Care Autonomy and Justice, (Westview Press, Boulder).

Colby, A, Kohlberg, L, Gibbs, J and Lieberman, M : 1983, "A Longitudinal Study Of Moral Development", Monographs Of The Society For Research Into Child Development 48(1-2), Serial No 200 .

Cohen, D V; 1995, "Moral Climate in Business Firms: A Framework for Empirical Research", in the Academy of Management 1995 Best Paper Proceedings.

Court M; 1994, Removing macho management: lessons from the field of education, Gender Work and Organization 1:1, January.

Curry, Janet M; 2002, "Care Theory and Caring Systems of Agriculture", Agriculture and Human Values; 19(2).

Dalley, A :1992, Inventing Motherhood, (Burnett, London)

D’Aquila, J :1997, “Internal Control Environment Forces and Financial Reporting Decisions Made by Financial Accountants", Unpublished Doctoral Dissertation, New York University

Darwall, Stephen :2006, "Contractualism Root and Branch: A Review Essay", Philosophy and Public Affairs 34(2), 193-215.

Davies, K: 1992, "Gender, History and Management Style in Nursing", in M Savage and A Witz, (eds.), Gender and Bureaucracy, (Blackwell, Oxford).

Derry, R :1989, "An Empirical Study of Moral Reasoning among Managers", Journal of Business Ethics 8, 855-862.

Dukerich, Janet M, Nichols, M L, Elm, D R, and Vollrath D A: 1986, "Moral Reasoning in Groups: Leaders Make a Difference", Human Relations 45(5), 473-493.

Dunfee T W and Donaldson T J,1994, Towards a unified concept of business ethics: integrative social contracts theory, Academy of Management review 19(4), 252-284.

Dunfee T W and Donaldson T J 1999, Ties that Bind: A Social Contract Approach to Business Ethics, Harvard Business School Press.

Dunfee T W and Donaldson T J, 2002a, Untangling the corruption knot: global bribery viewed through the lens of integrative social contract theory, in N E Bowie, ed., The Blackwell Guide to Business Ethics, 61-76, Malden, MA.

Dunfee T W and Donaldson T J, 2002b, Social contract approaches to business ethics; bridging the is ought gap, in R E Frederick, ed. , A companion to Business Ethics, Basil Blackwell, Maldon, MA.

Engster, Daniel: 2005, "Rethinking Care Theory: The Practice and Obligation to Care", Hypatia 20:3, 50-74.

Ferrell, O C, and. Gresham, L G.; 1985, "A Contingency Framework for Understanding Ethical Decision Making in Marketing", Journal of Marketing, 87-96.

Fineman, M: 2004, The Autonomy Myth: A Theory Of Dependency, (The New Press, New York)

Fishkin, J, Keniston, K, and Mackinnon, C :1973, "Moral Reasoning and Political Ideology", Journal of Personality and Social Psychology 27, 109-119.

Flanagan, O :1991, Varieties of moral personality: Ethics and psychological realism (Cambridge, MA, Harvard University Press).

Folbre, N: 2001, The Invisible Heart: Economics And Family Values, (The New Press, New York)

Gilligan, Carol: 1982, In a Different Voice: Psychological Theory and Women's Development, (Harvard University Press, Cambridge MA).

Gilligan, Carol: 1998, "Remembering Larry", Journal of Moral Education, 27(2), 125-141, June.

Goodwin, R: 1985, Protecting The Vulnerable: A Reanalysis of our Social Responsibilities, (Cambridge University Press, Cambridge). 
Goolsby, Jerry, and Hunt, Shelby :1992, "Cognitive Moral Development and Marketing”, Journal of Marketing, 55-68, January.

Hampton, Jean: 1998, Political Philosophy, Westview, CT.

Harris, J R :1990, "Ethical Values of Individuals at Different Levels in the Organizational Hierarchy of a Single Firm", Journal of Business Ethics 9, 741-750.

Haviv, S, and Leman, P J :2002, "Moral decision making in real-life: factors affecting moral orientation and behaviour justification", Journal of Moral Education, 31(2), 121-140.

Held, Virginia: 1993, Feminist Morality: Transforming Culture Society and Politics, (University of Chicago Press, Chicago).

Higgins, A :1989, "The Just Community Education Program; The Development Of Moral Role Taking As The Expression Of Justice and Care", in M Brabeck, (ed), Who Cares? Theory Research and Educational Implications of the Ethic of Care, 197-215.

Hirschi, T :1969, Causes of Delinquency, (University of California Press, Berkeley, CA)

Hoffman, M L :2000 Empathy and moral development: implications for caring and justice (New York, Cambridge University Press).

Hollinger, R C :1986, “Acts against the workplace: Social bonding and employee deviance”, Deviant Behavior 7:1, 53-75.

Hunt, Shelby D, and Vitell, S J: 1986, “A General Theory of Marketing Ethics", Journal of Macromarketing 6(1), 5-16.

Jaffee, Sara, and Hyde, J S :2000, "Gender differences in Moral Orientation: A Meta-Analysis", Psychological Bulletin, 126(5), 703-726, September

Johnston, K:1988, “Adolescents' Solutions To Dilemmas In Fables: Two Moral Judgment Orientations", in C Gilligan, J V Ward, and B Bardige, (eds.), Mapping The Moral Domain; A Contribution To Psychological Theory and Education, 49-69, (Harvard University Press, Cambridge MA).

Jorgensen, G :2006, "Kohlberg and Gilligan: duet or duel?", Journal of Moral Education 35(2), June, 179-196.

Juujarvi, S.; 2005, "Care and justice in real-life moral reasoning", Journal of Adult Development, 12(4), 199-210.

Juujarvi, S.; 2006a, "The ethic of care development. A longitudinal study among practical nurse, bachelor-degree social work and law enforcement students", Scandinavian Journal of Psychology, 47, 193-202.

Juujarvi, Soile: 2006b, "Care Reasoning in Real-life Moral Conflicts", Journal of Moral Education, 35(2), June, 197-211.

Kelley, S W, Ferrell, O C, and Skinner, S J :1990, 'Ethical Behavior among Marketing Researchers: An Assessment of Selected Demographic Characteristics', Journal of Business Ethics 9, 681-688.

Kittay E F: 1999, Love's Labor: Essays on Women, Equality And Dependency, (Routledge, New York).

Kittay, E F: 2001, "A Feminist Public Ethic of Care Meets The New Communitarian Family Policy", Ethics 111, April, 523-547.

Kohlberg L :1978, "The cognitive-developmental approach to moral education", in P Scharf, (ed.), Readings in Moral Education, (Winston Press, Minneapolis)

Kohlberg, L :1981, Education for justice - a modern statement of the Socratic view. In the philosophy of moral development, (Harper and Row, San Francisco).

Kohlberg L :1986, "A current statement on some theoretical issues", in S and C Modgil, (eds.), Lawrence Kohlberg: consensus and controversy, (Falmer Press, Philadelphia).

Kohlberg L, Levine, C, and Hewer, A:1983, Moral Stages: A Current Formulation and A Response To Critics, (Karger, New York) .

Krebs, D L, Vermeulen, S C, Denton, K L, and Carpendale, J I :1994, Gender and Perspective Differences In Moral Judgment and Moral Orientation, Journal of Moral Education 23, 17-26.

Kujala, J.: 1995, "Moral Issues in Business: Top Managers' Perceptions of Moral Issues in Stakeholders Relations", unpublished $\mathrm{PhD}$ dissertation, University of Tampere, Finland.

Linn, R :1995, "The claim for moral maturity, consistency, and integrity among objecting Israeli soldiers", Journal of Applied Social Psychology, 25(5), 399-417. 
Marks, Deborah :1997, "The Crafting of Care: Rationality, Gender and Social Relations in Educational Decision-Making", Gender Work and Organization 4(2) 87-98.

Meiland, J W :1980, “On the Paradox of Cognitive Relativism”, Metaphilosophy 2(2), 122.

Menzies Lyth, I :1988, "The functioning of social systems as a defence against anxiety", in his Containing Anxiety in Institutions: Selected Essays Vol 1, 43-88, (Free Association Books, London).

Noddings, Nel :1984, Caring: a feminine approach to ethics and moral education (Berkeley, CA, University of California Press).

Ponemon, L, and Gabhart, D: 1993, Ethical Reasoning in Accounting and Auditing (Canadian General Accountants' Research Foundation, Vancouver).

Reed, DC :1997, Following Kohlberg: liberalism and the practice of democratic community, (University of Notre Dame Press, Notre Dame, Indiana).

Rest, J. R.: 1986, DIT Manual, 3rd ed., 8/90 Revision (Center for the Study of Ethical Development, Minneapolis, MN).

Schwarzenbach, Sibyl: 1996, “On Civil Friendship", Ethics 107, October, 97-128.

Scanlon, T M, 1998, What We Owe to Each Other, Harvard University Press.

Sen, A K, 1997, Economics business principles and moral sentiments, Business Ethics Quarterly 7(3) $5-15$.

Sims, R L :2002, "Ethical rule Breaking by Employees: A Test of Social Bonding Theory, Journal of Business Ethics 40(2), October, 101-110.

Skoe, E E: 1993, "The ethic of care interview manual”, Unpublished manuscript, University of Oslo, Oslo.

Skoe, ER: 1994, "Ethic of Care, Justice, Identity, and Gender: An Extension and Replication", MerrillPalmer Quarterly 40(2), 272-289.

Skoe, E E :1995, "Sex role orientation and its relationship to the development of identity and moral thought", Scandinavian Journal of Psychology, 36(3), 235-245.

Skoe, E E: 1998, "Ethic of care: issues in moral development", in: E. E. Skoe and A. L. von der Lippe, (eds.), Personality development in adolescence: a cross-national and life-span perspective ( Routledge, London), 143-171.

Skoe, E E and Diessner, R :1994, "Ethic of care, justice, identity and gender. An extension and replication", Merrill-Palmer Quarterly, 40(2), 109-117.

Skoe, E E and Marcia, J E :1991, "A care-based measure of morality and its relation to ego identity", Merrill-Palmer Quarterly, 37(2), 289-304.

Skoe, E E and von der Lippe, A L :2002, "Ego development and the ethics of care and justice: the relations among them revisited", Journal of Personality, 70(4), 485-508.

Slote, Michael: 2000, Virtue Ethics, in H La Follette, (ed.), The Blackwell Guide To Ethical Theory, (Basil Blackwell, Malden, Mass).

Snell, Robin: 1996, "Complementing Kohlberg: Mapping the Ethical Reasoning Used by Managers for Their Own Dilemma Cases", Human Relations 49(1), 23-45.

Strike, Kenneth A : 2000, "Liberalism, Communitarianism and the Space Between: in praise of kindness", Journal of Moral Education, 29:2, June, 133-148.

Trevino, Linda K: 1986. "Ethical Decision Making in Organizations: A Person-Situation Interactionist Model." Academy of Management Review 11 (3): 601-617.

Tronto, Joan C: 1993, Moral Boundaries: A Political Argument for an Ethic of Care, (Routledge, New York).

Van Oosterhout J Hans, Heugens PMAR and Kaptein M, (2006), "The internal morality of contracting: advancing the contractualist endeavor in business ethics", Academy of Management Review 31:3, 521-539.

Victor, B, and J B Cullen: 1987, "A Theory and Measure of Ethical Climate in Organizations" Research In Corporate Social Performance and Policy 9, 51-71.

Victor, B, and J B Cullen: 1988, 'The Organizational Basis of Ethical Work Climates', Administrative Science Quarterly, March, 101-125.

Walker, M U: 1998, Moral Understandings: A Feminist Study in Ethics, (Routledge, New York).

Wark, G R, and Krebs, D L :1996, "Gender and Dilemma Differences In Real Life Moral Judgment", Developmental Psychology 32, 220-230. 
Wark, G R and Krebs, D L :1997, "Sources of variation in moral judgment: toward a model of real-life morality", Journal of Adult Development, 4(3), 163-178.

Wark, G R and Krebs, D L :2000, "The construction of moral dilemmas in everyday life", Journal of Moral Education, 29(1), 5-21.

Weber, M :1926, Politik Als Beruf, [Politics as Vocation] p57, Munich and Leipzig.

Williams, Patricia J, (1988), "On being an object of property", Signs: journal of women in culture and society, 14:1, 5-24, Autumn.

Wood, J T: 1994, Who Cares? Women Care and Culture, (Southern Illinois University Press, Carbondale). 